\title{
The legacy of ERA, privatisation and the policy ratchet
}

\section{Stephen J Ball}

\section{paper for EMAL}

\section{Introduction}

This paper will explore some of the ways in which the neo-liberal impetus toward the privatisation of state schooling signaled in the Education Reform Act 1988 (ERA) has become embedded in the English school system through a variety of related and subsequent policy moves, devices, programmes and initiatives. Four main points will be made. First, that ERA itself was of huge strategic rather than substantive importance as far as privatisation is concerned. For the first time it made privatisation thinkable as a practical policy option for state education and introduced a basic 'market form' into state education (see Ball 1990). Second, by tracing the lineage of privatisation from ERA onwards the 'ratchet' effect of small and incremental policy moves can be identified, which have disseminated, embedded and naturalised privatisation within 
public sector provision. Third, that while privatisation has been taken up and taken much further by New Labour than it had been by the Conservatives there are differences between the two sets of governments in the role of privatisation in education policy and the role of the state. Fourth, the participation of private providers in the planning and delivery of state services has put the private sector at the very heart of policy. I will say something about both 'endogenous' and 'exogenous' privatisation but will concentrate primarily on the latter. At points in the paper I will draw upon interviews conducted with private sector providers (see Ball 2007 for details).

The importance of ERA in the history of English education is undeniable. It was both a decisive break from the short-lived, half-hearted comprehensive education experiment and a reinvention of $19^{\text {th }}$ century themes and patterns in state education. In this paper however I want to concentrate on what ERA did not do or more precisely did not do but made possible. ERA created the possibilities in legal, political and discursive senses for a set of profound and inter-linked changes in the paradigm of English education policy. Specifically ERA and other related legislation made it possible within 
policy to think about private sector participation in and delivery of state education services. However, this possibility of policy thinking has been taken much more seriously and much further by the post-1997 Labour governments.

The privatisations set in train by the ERA were of two sorts - what Hatcher and Hirtt (1999) call endogenous and exogenous. The former denotes the creation of market-relations within and between public sector providers which require them to act like businesses and be business-like. In education this was enabled by a combination of parental choice, devolved budgets and other organizational autonomies, per-capita funding, the provision of market information through testing and examination performances, published from 1992 on in the form of League Tables, and various moves (City Technology Colleges (CTCs), Grant-Maintained Schools (GM) alongside the preservation of Grammar schools) to increase the range of types of school available for choice. In regards to all of this ERA established a form of 'fragmented centralisation', taking away established autonomies from schools (in curriculum and assessment) and granting them new ones (Local Management of Schools (LMS)), centralising and devolving simultaneously, and in the process significantly reducing and 
undermining the roles and powers of LEAs. Despite the neo-liberal influences which bore upon it the emphasis of the ERA is state-centred. In particular there was an accretion of an enormous number of new powers of various kinds to the Secretary of State. The education market created by ERA and other legislation gave an impetus to schools to act independently and competitively but at the same time subjected to them to the disciplines of market relations as conjured up within Hayekian economic and market theory (Hayek 1980). The key aspects of market theory enacted in ERA were that informed choosers (parents) would select the best performing schools for their children, which would respond by expanding their intakes, while poor performing schools would improve themselves in order to survive, or face 'bankruptcy' (as Keith Joseph put it when I interviewed him in1989, see Ball 1990). In practice of course the school market rarely actually operated in this way. However, choosing proved to be a very social and cultural practice only partly related to market information. Few successful schools sought to grow their intakes, despite special funding being made available by Kenneth Clarke in 1992, creating both over- and under-subscription and a failure to clear. Indeed successive governments have found parental choice and school supply extremely difficult to manage. 
In addition, a continuing commitment to selection of various forms by both Conservatives and Labour has distorted the freedom of the market giving power back to some producers and further complicating the process of choice. Nonetheless, the insertion of market relations into state schooling has gone some way towards creating a new 'ethical environment' (Blackburn 2001) within which practitioners operate. Indeed, some schools have indulged in 'opportunistic behaviours' of various sorts to control their intake and maximise their performance indicators. One of the effects being the creation of local 'economies of student worth' within which schools compete to recruit 'value-adding' students, those most likely to contribute to measurable 'improvements' and 'performance outputs', and those easiest and cheapest to teach, and whose presence attracts others like them. Concomitantly, those students who add 'negative-value', those with special Needs, those for whom English is a second language, or those with social or emotional difficulties are avoided where possible in this economy .

In some respects, in relation to some of the economic thinking in and around the Conservative Party at the time of the ERA, these moves to create a school market were modest. There were 
more radical ideas being mooted, like Junior Education Minister Bob Dunn's proposal for an experiment involving 'crown and company schools'. However, as indicated already my argument is that the overall significance of the ERA as regards privatisation generally was strategic rather than substantive and in both respects has to be considered alongside a number of other policy moves toward privatisation in or related to education which created windows of opportunity for and raised the ambition of private providers. The introduction of LMS (giving schools control over their devolved budgets) and the changes this brought to LEA budgets, together with other powers and responsibilities lost by LEAs, as a result of ERA and other legislation, gave direct and indirect impetus to new forms of exogenous privatisation in education. Some LEA Officers who were made redundant as a result of ERA and others who gained experience, as a result of ERA, of the commercialisation of LEA services saw the possibility of new challenges and career opportunities in setting themselves up as private providers of education services. Several 'education businesses', some of them now major players in the Education Services Industry (ESI), had their beginnings at this time, like Cambridge Educational Associates (CEA, now part of Mott MacDonald) and Prospects. Three examples: 
Baker [Conservative Secretary of state for Education] got behind the LMS movement in Cambridgeshire, where it did have party support and was going great guns, except that Cambridgeshire got somewhat bored with being the magnet for everybody from all over the country, and indeed internationally ... Brian Smith was pretty passionate about it as was I and took early retirement and set up CEA with a view to propagating LMS. (Derek/CEA)

I spent a fair amount of time throughout my career working at education-business partnerships with local training enterprise councils and that sort of thing. And, in the area of school support services, and local education authority support services, during the latter part of the nineties things really began to happen. A number of companies set themselves up, focused in that area. (David McGahey/VTES)

... at that stage when I was working in a local authority I had an opportunity to take the service that I was running so that it operated at arm's length from the local authority. And that gave me a little bit of a taste for getting involved in running a 
business ... I'd always had small business sidelines myself anyway, so when the opportunity came with the privatisation of the careers services in the early nineties I moved out of local authorities at that point and started up Prospects. (Ray Auvray/Prospects)

Other Conservative privatisations created other starting points or possibilities for privatisation including involvements within service delivery (CTCs and specialist schools), vouchers for parents, ofsted contracts, the Private Finance Initiative and Compulsory Competitive Tendering (CCT). CCT was introduced in an attempt to bring greater efficiency to local government and health services through the use of competition. It broke the Local Authority monopoly of service provision through direct labour by requiring councils to contract services to the lowest bidder and transfer workers to private providers. Compulsion resulted in resistance by local authorities and health trusts, and an immature market and poorlyconducted procurements which focused on price at the expense of quality and employment conditions. It was replaced under Labour by 'Best Value', which shifted from an adversarial to partnership relationship between councils and the private 
sector and from cost reduction to quality (Kirkpatrick 1999). The CTCs programme encouraged and enabled businesses and business people to 'sponsor' and get involved in running state schools with a vocational orientation - fourteen colleges were established by 1997. This provided part of the model for Academies (see below). Specialist Schools was an initiative launched by Kenneth Clarke in 1992 which enabled GM and Voluntary-aided schools to develop a curricula specialism with the aid of private sponsorship money, matched by Government funds. The scheme was expanded and developed by Labour so that currently over $80 \%$ of all secondary schools have specialist status. The creation of Ofsted, the Office for standards in Education, was accompanied by the contracting out of school and FE inspections to private companies. At one point there were 120 recognized contractors but this has now been reduced to the 'big 5' which hold all the seven national Inspection contracts (five regions, Further Education and Private schools) between them: Nord-Anglia, Tribal, Prospects, CEA and CfBT. As rehearsed already, parental choice (1980, 1986, ERA), per-capital funding (ERA) and the publication of school League Tables (1992) created the infrastructure for endogenous privatisation as a result of which schools were 'encouraged' to compete for recruitment and 
employ promotional techniques (see Gewirtz, Ball et al. 1995) to attract choices. These 'moves' were briefly preceeded by a small pilot scheme of 'school vouchers' in parts of kent initiated by Keith Joseph but deemed a failure by the civil service and taken no further. In addition, in 1996 a pilot National Nursery Voucher Scheme (NNVS) was introduced in four local authorities (developed and implemented by CAPITA), which allowed parents to 'spend' their voucher in state or private nurseries and which unintentionally led to an enormous expansion in the number of state school nursery departments. The Conservatives' 1997 Election Manifesto pledged to extend the scheme nationally but it was abolished by New Labour. Finally, the Private Finance Initiative was launched in 1992. This involves local authorities, health trusts and government departments contracting a private firm to finance, design, build and manage public projects such as new roads, schools, prisons and hospitals. After building the project, the private contractor rents the finished project, plant and services, back to the public sector. By the end of 1997123 such projects had been signed with a capital value of $£ 6 \mathrm{bn}$. These rather disperate policy ideas drew on a variety of sources and originators with somewhat different political views (including Joseph, Thatcher, 
Baker, and Clarke) but were generally informed by the Conservative's ideological commitment to Hayekian, neo-liberal, market theory and their thorough-going distrust of public sector organisations generally and teachers in particular. However, they never formed a coherent strategy of privatisation within education although as indicated ERA did in effect bring into play most of the key features of the 'market form' .

Exogenous Privatisations

The longer term significance of all of these initial moves, with the exception of NNVS, which New Labour abolished, and, as yet, Vouchers, is the extent to which they were taken up and developed much further by New Labour. When Labour came to power in 1997 Inspections and a great deal of Teacher Supply were run by private companies. By 2002 the Teacher Supply business was worth $£ 600 \mathrm{~m}$ pa., (see Hutchings 2006). LMS had created a new 'retail market' in educational services to schools; back-office, ITC and Technical support were increasingly provided by the private sector. Commercial and charitable sponsors were involved with CTCs and specialist schools. PFI schemes were increasing in number modestly but steadily. Consultants were 
increasingly commonplace within government and its agencies, and in particular in the $\mathrm{FE}$ sector which had been incorporated in 1992. In effect an infrastructure and a set of starting points for a much more thorough-going process of privatisation were established and were taken very seriously by the post-1997 Labour Governments as a central strategy in their agenda of public sector modernization.

In developing greater choice of provider, the private and voluntary sectors can play a role. Contrary to myth, no-one has ever suggested they are the answer. Or that they should replace public services. But where use of them can improve public services, nothing should stand in the way of their use. In any event, round the world, the barriers between public, private and voluntary are coming down ... if schools want a new relationship with business in their community, as many do, let them ... What I'm saying is let the system breathe; develop; expand; let the innovation and creative ideas of public servants be given a chance to flourish. ((Prime Minister's Speech on Public Service Reform, 16 $6^{\text {th }}$ October 2001. Available online: http: / /www . number10.gov.uk/output/Page1632.as p From www.direct.gov.uk ). 
For example, Labour has introduced the outsourcing of LEA and Children's services, and schools and policy programmes (see below). Labour also built upon and expanded enormously the PFI initiative. By 2003 the PFI debt market stood at $£ 8.2$ bn up from $£ 4.9$ bn the previous year.

'According to the Treasury, PFI transactions with a total capital value of $£ 35.5 \mathrm{bn}$ have been signed since April 2003' (UNISON 2004). By the end of 2004 there had been 667 signed projects with a total capital value of $£ 42 \mathrm{bn}$. PFI projects made up between 10 and 13.5 per cent of the UK Government's investment in public service infrastructure between the years 1998-9 and 20034 (ESRC Society Today). By September 2006 the capital value of PFI projects had risen to $£ 47$ billion (Unison 2006 Positively Public briefing). There is now an extensive secondary market in PFI contracts.

Education Action Zones, an initiative launched in 1998 (see Gewirtz 1999), offers an example of a short-lived policy experiment which brought together a number of new forms of funding and local social relations which typify New Labour's 'Third Way' policies, including the use of contracting as a means of resource allocation, by which local partnerships, including business 
partners, had to tender for Zone status and possibilities for varying teachers' pay and conditions of work. EAZs were another 'move' in the involvement of the private sector on the planning and delivery of state schooling, which was taken still further in the Academies programme and Trust schools legislation. The Academies programme was launched in the Learning and Skills Act (2000). Many existing or proposed Academies have private sector sponsors - either individual entrepreneurs or companies (see [Woods, 2007 \#1660]. The 2006 Education and Inspections Act created a new category of Trust schools and several private companies (education businesses and others) have indicated an interest in forming or being part of Trusts to run such schools.

New Labour has also vastly increased the use of private consultants in the business of government. Figures from the Office of Government Commerce show that spending on consultants rose by 42 per cent in 2004-05 from £1.76 billion in 2003-04.

Some private consultancies are now focusing entirely on public sector contracts, which can attract fees of up to $£ 2,000$ per day. Firms are being hired to advise on 
outsourcing, to "manage change", to set up IT systems, to advise on advertising and communications and to conduct polls and surveys' .

(The Times 24th Sept 2005)

This increased use of consultants partly resulted from the 2004 Gershon Review of public sector efficiency and the proposal to save $£ 20$ billion in the public sector and improve frontline services through 'out-sourcing'.

There is not enough space here to discuss all of these developments fully. I will address further just two; contracting out and improvement services.

Out-sourcing

Out-sourcing in education takes numerous forms and again I will discuss two. They are, the contracting out of organisational management (schools, Children's Services and LEAs) and the contracting out of policy programmes (the National Strategies, careers advice etc.).

The out-sourcing of education services is worth at least $£ 1.5 \mathrm{~b}$ a year. Probably most attention has been given to the out-sourcing of LEA 
services, although this appears, for the time being at least, to have ended. The Conservatives gave Ofsted powers to inspect LEAs in 1996 and New Labour used these Inspections to identify 'failing' LEAs. Procedures in the 1998 Schools Standards and Framework Act enabled the Secretary of state to bring private education companies into the management of failing LEAs. The first such contract was awarded on 1 July 1999 to the stock-exchange listed education company Nord Anglia to run the School Improvement Service in Hackney. Which was in its turn found to be inadequate by Inspectors. These contracts normally arise from serious concerns about LEAs' performance and capacity identified in ofsted (see Campbell, Evans et al. 2004) and subsequent 'recommendations' made by consultants (PriceWaterhouseCoopers (PWC) in many cases) to the DfES and negotiations between the Authorities concerned and the DfES about appropriate remedial action - consultants are also employed to write the resulting contract when private contractors are used. However, not all authorities in difficulties have been out-sourced and outsourcing is one of a number of 'experiments' by the DfES to encourage 'new ways of working' by LEAs. The evaluation of these 'experiments' by Bannock Consulting (Bannock 2003) identified 44 (sic); 11 interventions leading to out-sourcing; 
11 interventions of other kinds; 10 New Models funded by the DfES; and 11 independent innovations. Then again some of the funded examples (e.g. Surrey/VTES, Black Country Partnership, Wirral) and independent examples (e.g. Bedfordshire a 12 year contract with HBS now terminated, see below) did involve contracts with private companies and in several other cases external consultancy support and advice was commissioned (CAPITA worked with Oxfordshire, West Berkshire and Wokingham), in most cases but not all, from the private sector. Two of the outsourced authorities, Swindon and Haringey have subsequently returned to local authority control, a third Islington is negotiating with its provider (CEA) for a voluntary extension to the contract. Hackney is out-sourced to a not-forprofit Trust and Education Leeds is run on a notfor-profit basis by CAPITA. In these terms local authority out-sourcing has not, thus far, proved to be the sort of major market opportunity (or privatisation nightmare) it was originally thought to be.

However, in some ways the LEA contracts are the tip of the iceberg as regards out-sourcing at this level. Large numbers of Local Authorities have whole or partial out-sourcing of their other services driven by the findings of Best value 
reviews - Housing Benefits and other financial services in particular. Four companies dominate in the provision of these services - CSL (Sheffield, Southwark, Newham, North Somerset, Taunton etc.), CAPITA (Lambeth, Westminster etc.), EDS (Brent, Kingston, Wandsworth etc.) and ITNET (Islington, Hackney etc.). In some cases these contracts take the form of Strategic Partnerships (Lincolnshire, Norfolk, Sheffield etc.) within which private contractors take-over a wide range of often very different local authority services. In June 2001 HBS (see below) was awarded a 12 year $£ 267 \mathrm{~m}$ Strategic ServiceDelivery Partnership (SSP) by Bedfordshire County Council covering financial, information technology, human resources, schools support services and contracts/facilities management, some 550 staff were transferred to HBS (see (CPS 2005). In 2005 the county terminated the contract; 'The council considers and is so advised that HBS was in breach of a number of its obligations under the Services Agreement' (http: / / www.publictechnology.net/modules.php? $\underline{\mathrm{op}}=$ modload\&name=News\&file=article\&sid=3646 ). The cost of the termination to the Council was $£ 6.75 \mathrm{~m}$.

The point here again is the scale, complexity, diversity and relative invisibility of private 
sector involvements. Furthermore, the majority of the private sector involvements with Local Authorities and LEAs did not stem from interventions, although they may have been encouraged in various ways or made necessary by the contestability requirements of Best Value and CPA reviews ${ }^{1}$. However, the spate of LEA contracts has virtually dried up but this may be a period of hiatus as Children's Services structures are established at Local Authority level. One such contract has been awarded in North East Lincolnshire, a 3 year $£ 200,000$ pa contract to Mouchell Parkman and Outcomes UK.

At the school level the 'contracts market' is even less well developed. Only four secondary schools, three of them in Surrey, are fully outsourced, two are run by 3Es (Frenchay and King's College) - 3Es has now been taken-over by Dubaibased company GEMS (General Education Management Systems) - and one, Abbeylands is run by NordAnglia. The fourth, Salisbury school in Enfield was contracted out in 2007 to the UK subsidiary of US company Edison. Another primary school in Tower Hamlets, Rams Episcopal was managed for a short time by CfBT. This level of outsourcing is much more developed in the US but is still small-

${ }^{1}$ Comprehensive Performance Reviews are conducted by the Audit Commission and deliver an overall judgement based on the delivery of cores services and corporate strength of each local council (see ODPM website). 
scale, with Edison as market leader. In 2003

Edison ran one-quarter of the 417 contracted-out schools in the US, teaching 132,000 students in 20 states - a tiny proportion of US schools. The major inhibitors in terms of further developments in England are a lack of interest on the part of LEAs and on the part of providers, most of whom see little opportunity for efficiency savings and profit in running single schools. Rather as Neil McIntosh of CfBT explained:

... essentially being the managers of a group of schools is what we aspire to. And I've been saying since, well since the beginning of the labour government that the model for us exists in the independent sector, which is the Girls Public Day School Trust, which has 25, 30 schools, I'm not saying that everything in that model we would mirror and we are certainly not interested in it being intellectually or socially exclusive come to that, but in terms of a managerial model it's interesting .

In principle that's something we would be quite interested in if the government now, or at any point in the future, was to do a Sweden and allow the private sector to- to operate schools within the state system, then 
we would certainly be interested in that ... in Scandinavia at the moment there are some, I think, some very interesting examples of school systems that are owned in different ways: private sector, voluntary sector, faith, state ... this is the sort of thing that could be in either or both political manifestos the election after next. (David McGahey/VTES)

It may be that the development of federations of schools and the possibilities of Trust schools created by the 2006 Education and Inspections Act will in the future provide the conditions of participation sought by the private providers. CfBT was one of four bidders to found a new secondary school in Haringey and hoped to so in the form of a Trust but the consultation process led to the recommendation of a new community school. 
Policy Programmes is a rather loose category used here to refer to national schemes of various kinds which are contracted out to private providers. These can range from IT and management systems to pedagogical or curricula initiatives (see Box 1.). Among the former are various systems management contracts held by CAPITA including PLASC (Pupil level annual school census), TPS (Teachers' Pension Scheme $£ 62 \mathrm{~m}$ ), ILAs (Individual Learning Accounts now terminated), school admissions, Education smartcards ( $£ 100 \mathrm{~m}$ over seven years) and Children's' Trust accounts ( $£ 430 \mathrm{~m}$ over 20 years). CAPITA is the specialist provider of such services. In 2005 CAPITA also took over the contract for the National Learning Strategies (Literacy and Numeracy from CfBT) (worth $£ 177.5 \mathrm{~m}$ over 5 years).

Box 1. Privatized programmes

\begin{tabular}{l} 
Teachers TV The channel will be run by Education \\
Digital, an independent consortium made up of \\
Brook Lapping Productions, ITV and the Institute \\
of Education with an annual budget of $f 20 \mathrm{~m}$ \\
\hline Connexions - a national scheme of careers and \\
training advice for young people. VT Education \\
and Skills is the Market Leader here and \\
nationally the largest provider... but Prospects is
\end{tabular}




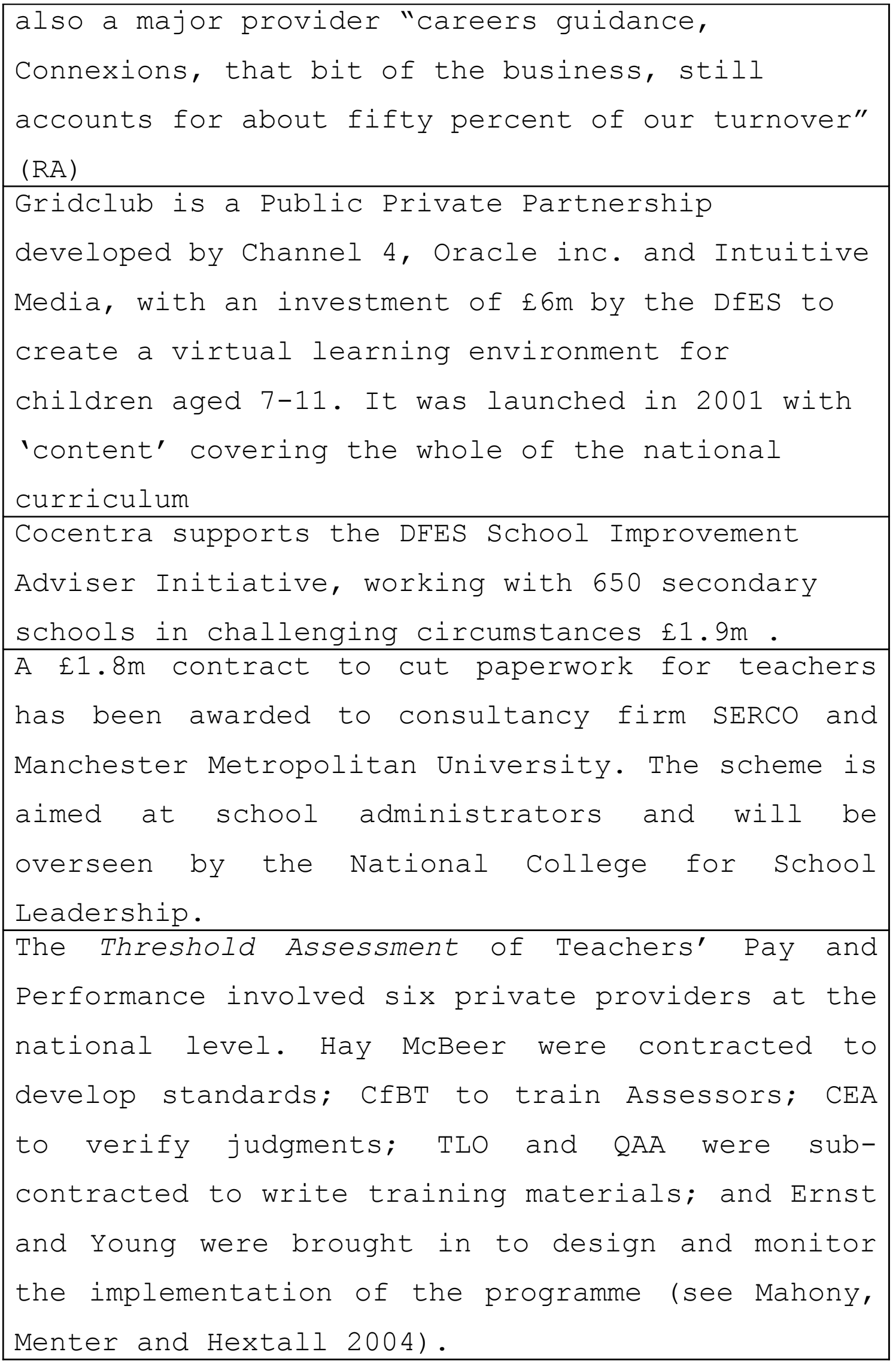

Here the private sector is either taking over 
existing in-house government or local services (like Careers Advice) or taking up new opportunities (like Gridclub and Teachers Television) but mainly the latter.

Improvement Products

LMS, as noted already, both positioned schools as 'buyers' of services and was a major factor in bringing about the dismantling of LEA services to schools. There is now a retail market in the sale of single services or packages of services to individual schools or LEAs ranging from 'hard' office, financial and facilities services to 'soft' school improvement and CDP work and what Tribal call 'turnaround services', aimed at supporting weak or 'failing' institutions. Services companies will also help schools prepare themselves for ofsted Inspections and mentor and train senior staff in the management roles and provide 'interim management'.

A significant part of this 'soft' work involves responses to government policy changes and initiatives in relation to curriculum requirements and related developments (see below). The private sector fills the gap left by the reduction in funding of Local Education Authorities to interpret and mediate policy for 
schools. So for example HBS' education business is "Ninety-five percent curricular and national agenda activities, standards funds, five percent back office ... we're directed primarily at school improvement and enabling change in schools" (Peter Dunne). This softer work, 'the management of change', is a niche market for smaller education services companies like Edunova, Edison and Cocentra.

For private providers New Labour education policies and reforms are specific opportunities for profit in two senses. First, policies which announce 'zero tolerance of underperformance' and intervention in underperforming schools (Excellence in Schools 1998 Internet Summary) provide opportunities for replacement and/or remediation of 'failing' or 'weak' public sector institutions. The education businesses can sell school improvement - offering schools ways of accommodating themselves to the demands of performativity and producing new organizational identities and 'turnaround services' to those schools and colleges which are 'struggling' to respond to the requirements of performativity. Second, taking up spaces 'vacated' by LEAs and other state organizations, these companies mediate between policy and institutions, making policy manageable and sensible to schools and to 
teachers. On behalf of the state, in effect, they disseminate the discourses of reform, of improvement and of competition. These services are represented in the company's improvement brands: Cocentra offers 'futureproofing'; Tribal will make you into 'Pupils' Champions', EdisonSchoolsuk sells the 'Edison Design', which includes coaching and performance management systems; Mouchell Parkman deals in 'enabling improvement' and 'collaborative development'; Edunova has 'Learning Led Design' and stresses that 'Innovation can only be effective as part of a process of school transformation if it arises naturally from a culture that accepts change and continuous improvement as a way of life'; Prospects offer Performance Life Coaching; and CEA can provide 'Leading School Improvement Solutions'. The brochures and websites which promote these services are 'breathlessly enthusiastic' (Parker 2000 p. 9), energetic and bold, they promise to solve school problems. For example, 'HBS Education has a mission to support all parties engaged in raising standards and transforming the way we learn ... Introducing a bold change strategy to transform the way we teach and learn in this century, requires new ways of looking at problems and how we solve them ... HBS is one of a new breed of solution providers in education'. Central to all of this is what 
Fullan (2001) calls 'reculturing' - which draws its language and methods from business models of change management and which Parker (2000 p. 11) sees as a shift from bureaucracy and its inefficiencies to 'caring about customers, being innovatory, focusing on quality and so on ...' What are being sold are the urgencies of change, a new language for organizational life and a kind of self-belief and self-efficacy - the mentalities and sensibilities of the private firm. Here the work of exogenous privatisation which brings about further moves in endogenous privatisation.

Conclusion

Under Conservative governments until 1997 and New Labour since that time a whole set of changes in education policy which were initiated by ERA have been working, developing and expanding through a 'ratchet effect' of changing practical and discursive possibilities (see Ball 1990). That is, an incremental process of breaking up established assumptions and modes of operation and taken for granted practices and replacing these with new 'freedoms', new players and new kinds of relationships and new forms of service delivery in many different parts of the education system, all scaffolded by a constant flow and 
reiteration of political rhetoric emanating from diverse sites and sources. Sometimes this process involves modest 'moves' and changes, sometimes bold ones. "If anything we have not pushed fast enough and hard enough" (Tony Blair, Labour conference 2005). Sometimes the progressive creep goes too far or too fast and is interrupted or compromised, most dramatically in the case of the 2006 Education and Inspections Act (see Ball 2007b) and not every policy move contributes directly to major or wholesale change. It is the steady accumulation and combination of moves that is important. Each move makes the next thinkable, feasible and acceptable and over time and as a result the private sector or private forms of provision become ever more deeply embedded in the texture of the public services. The process of public sector 'modernization' or transformation involved here is both creative and destructive, a process of attrition and re-invention. As Whitfield argues 'although the transformation process may sometimes appear to be disjointed or uncoordinated' (Whitfield 2001 p. 69), it has an internal logic, a set of discernible, if not necessarily planned, facets.

As a result of this ratcheting process the private sector is now thoroughly inter-twined in the day-to-day business of decision-making, 
infrastructural development, capacity building and services delivery in state education at all levels. Furthermore, the policy work of the state is now routinely informed, monitored or taken over by private providers either in the form of consultancies, evaluations or reviews, or programme delivery, this is what Mahony, Menter et al. (2004 p. 207) call 'privatizing policy', and they 'contend that such has been the central involvement of some of these companies that they should be seen as part of the policy creation community'. Through these involvements networks of social relations are established between politicians, civil servants and business (and charities and voluntary organizations) which inform and influence policy thinking about education and indeed there is considerable movement of personnel between state and public services and the private sector (see Ball 2007 a Chapter 4).

Within these networks, the distinctions between advice, support and lobbying for work are sometimes hard to see. Private consultants are routinely contracted to give advice on the future organization of government or local government services or are members of taskforces which almost without exception produce recommendations for further privatisations and out-sourcing. In 
turn, out-sourcing has generated a subsidiary 'transaction' business which provides a constant stream of work for the Big Four companies of auditors and management accountants, and the corporate law firms responsible for drawing up hundreds of thousands of contracts and subcontracts with all those private providers' (Pollack 2004 p. 214). Prevailing policy discourses which circulate in and are legitimated by these networks privilege privatisation(s) as the solution to almost every problem of government.

However, under New Labour this process of privatisation is primarily pragmatic and experimental rather than ideological, as was the case under the Conservatives, and it is about 'what works' rather than a straightforward political commitment to a vision of 'the market relation' as the organizing principle for society. The current education market is not a neo-liberal free market, neither in its endogenous nor exogenous manifestations, it is a state-regulated market and a means of governance. Indeed the state is a market maker, New Labour has made attempts to grow the ESI market by bringing new players into the running for contracts, although not always with success (e.g. Atkins and Jarvis). Alongside of this, there is 
also a major impetus to private-public

partnerships as a form of hybrid privatisation (an endogenous/exogenous mix). Nonetheless, there are indications that new opportunities for private sector participation may arise in the future, for example as indicated, through the creation of Trust schools, and in 2006 a PWC report for the DfES Children's Services Markets, put 'forward six overarching suggestions on how the DfES could further develop children's services markets in line with its policy on contestable markets' (p. 5). There may well be more moves imminent in the policy ratchet of education privatisation(s) which was set in motion by ERA.

What was begun by the ERA is arguably a profound change in the basic organising principles of the English education system. What Hall and Schwarz (1985) called the 'peculiarly British collectivism' which was invested in the 1902 and 1944 Education Acts, which gave rise to a 'national system locally delivered', is being unravelled. The unravelling was begun in earnest by ERA which introduced new sorts of 'independent' schools, GM and CTCs (which were added to later by Specialist, Academy and Trust schools). ERA also played a significant part in the disempowerment and displacement of teacher 
unions and of teacher control over curriculum decision-making and assessment and the systematic marginalisation of LEAs, with a concomitant enhancement of parental voice and choice, a shift, symbolically at least, from supply to demand side planning, which has also continued. The liberal political ideology within which state education was constructed in the nineteenth century and which Green (1991 p. 7) suggests 'continued in modified form into the modern period and has continued to undermine efforts to create a viable system of public education to this day' was decisively reasserted by ERA. The deep political irony is that this reassertion is now being pursued to its conclusion by New Labour .

However, in a different spatio-temporal perspective the continuities between the Conservatives and New Labour, as well as the differences, might be explained in terms of general socio-economic global changes. That is, as adaptations to a new regime of capital accumulation and recalibrations of educational organisations in response to the 'necessities' of globalisation and the knowledge economy in particular. In other words, these periods in government represent two stages in moves towards a new form of social regulation - a new ensemble 
of institutions, organisations, social forces and actions, a new 'social fix' as Jessop (2002) calls it. A Schumpeterian fix to replace the previous Keynsian one, with a new set of political and economic strategies. These include a 'tightened connection between schooling, employment, productivity and trade' (Jessop 2002 p. 165). It is aspects of this tightening which are outlined above.

References

Ball, S. J. (1990). Politics and Policymaking in Education. London, Routledge.

Ball, S. J. (2007). Education PlC: Understanding private sector participation in public sector education. London, Routledge.

Ball, S. J. (2007). "Going further?": Tony Blair and New Labour Education Policies. in K. Clarke. (Ed.) SPA Policy Review 2006. Bristol, Policy Press.

Bannock, C. (2003). Evaluation of New Ways of Working in Local Education Authorities. Volume 1 - Main Report, DfES.

Blackburn, S. (2001). Being Good. Oxford, Oxford University Press.

Campbell, C., J. Evans, et al. (2004). Evaluation of Education Partnership Boards. London, Institute of Educatrion, University of London.

CPS (2005). Strategic Partnership in Crisis: An investigation of the Strategic-Delivery Partnership between HBS Business services group and Bedfordshire county Council. Bedford, Bedfordshire Unison.

Fullan, M. G. (2001). Leading in a culture of 
Change. San Fransisco, Jossey Bass. Gewirtz, S. (1999). Education Action Zones: emblems of the Third Way? in $\mathrm{H}$. Dean and R. Woods, (Eds.) Social Policy Review 11. Social Policy Association.

Gewirtz, S., S. J. Ball, and R. Bowe (1995). Markets, Choice and Equity in Education. Buckingham, Open University Press.

Green, A. (1991). The peculiarities of English education. Education Limited: Schooling and Training and the New Right since 1979. Education Group, CCCS. London, Unwin Hyman. Hall, S. and B. Schwarz (1985). State and society, 1880-1930. in M. Langan and B. Schwarz. (Eds.) Crises in the British State 1880-1930. London, Hutchinson.

Hatcher, R. and N. Hirtt (1999). The Business Agenda behind Labour's policy. Business, Business, Business: New Labour's Education Policy. M. Allen. London, Tufnell Press. Hayek, F. (1980). Individualism and Economic order. Chicago, University of Chicago Press. Hutchings, M. (2006). Private teacher supply agencies: an under-researched aspect of private sector activity in education, Institute for Policy Studies in Education, London Metropolitan University.

Jessop, B. (2002). The Future of the Capitalist State. Cambridge, Polity Press.

Kirkpatrick, I. (1999). "The Worst of both Worlds: Public services without markets of bureaucracy." Public Money and Management $19(4): 7-14$.

Mahony, P., I. Menter, et al. (2004). "Building Dams in Jordan, assessing teachers in England: a case study in edu-business." Globalisation, Societies and Education $2(2)$ : 277-296.

Parker, M. (2000). Organisational Culture and Identity: Unity and Division at Work. London, Sage.

Pollack, A. (2004). NHS plc: The Privatisation of Our Health Care. London, Verso. UNISON (2004). PFI: Against the public interest: 
Why a 'licence to print money' can also be a recipe for disaster. London, UNISON.

Whitfield, D. (2001). Public Services or

Corporate Welfare. London, Pluto Press. 